\title{
Working title: Digital Spiritual Embodiment: Power, Difference, and Interdependence
}

Kate Ott

The self as networked in a digital era seems to be a consensus point among technologists and theologians. Networking as the primary organizing principle of digital existence relates to hardware and software and online and offline connections between others and one's self (Campbell and Garner 2016; Rainie and Wellman 2014). I appreciate this shift in perception or description as the primary way of being in a digital world. The "new" way of being in digital networked relationships matches feminist and womanist theological constructions of personhood and agency that have long argued for relationality and interdependence. These theologies push western Chrisitanity away from centralizing autonomy, rationality, and independence as key features of personhood. In response to this push, concerns arise that interdependence, relationality, affective forms of knowledge, and difference trouble easy assessments of accountability and ultimately punishment. Individual sin is recast in the network of social or communal sin in womanist and feminist understandings. These movements also require theology to be historically and contextually located, paying attention to the embodied life of Christians. Yet, few womanist and feminist theologies have sought to engage questions of how digital technology, new form of being that is not only spiritual and embodied, but digital, related to theological anthropology.

I continually return to a quote by feminist, Ghanian theologian, Mercy Oduyoye, in telling the narrative of how her relationship to her mother informs her theology, she writes, "Blood may be myth, genes too scientific, but there is nothing like a story to help fix one's selfimage" (Oduyoye 1988, 35). By self-image, I take her to mean a sense of self in a deep and abiding way that relates to who we are as created by God and shaped by those in our lives--a theological anthropology. Story or lived experience are a cornerstone for feminist theological reflection. Here I will begin with three stories or iterations of stories. They exemplify moments of encounter between a reader, a story, and the new narrative that arises. Then, I bring representative feminist and womanist theologies into conversation with the themes in these stories to propose a vision that incorporates and disrupts digital aspects of theological anthropology. These stories show liberative aspects of digital technology, and also demonstrate the confining and disciplining powers embedded in technologies that perpetuate systemic sin reinforced by human actions and now, artificial intelligence or machine learning. 


\section{Generative Stories}

Story One: "Smug email me is not my only online incarnation. There are dozens more of my avatars scattered across the web." Incarnation is a conspicuous choice of words when avatars are all but fleshly embodiment from a Christian point of view. But taken from the Hindu tradition, incarnation is any of one's lifetimes, though the meaning is still not devoid of a lived, material existence and certainly only happens one at a time. The original use of avatar is from the Hindu tradition, the columnist Amanda Hess tells me. Avatars are forms that gods take to descend to the earth. Yet, a small group of early adopters of digital technology reconceived the avatar. "The technological co-opting of the word replicated the power dynamic in the original avatar myth the avatar helps a higher being interact with a lesser realm, one he or she controls. But it also retained the idea of the avatar's task of delivering righteousness to a lawless world." Mostly geeky, young people with few connections offline claimed social status through their online avatar's embodiment, a marker of their technological creational prowess. The question at this point in our digital lives is whether our online representations are us, not in the sense of representational, but substantively making us known to ourselves and others. "Our avatars represent a self image that's fractured across dozens of sites and text bubbles and email chains." What is the distinction between self image or other's image of us and personhood? Is there a difference between a bitmoji and a facebook profile picture (usually a photo of oneself)? Which form of communication--text message, voice memo, or talking self-designed emoji-- is the true me? In other words, am I digitally incarnated? And if so, does that incarnation carry the image of God the same as my fleshly incarnation does? (Hess, 2016)

Story Two: "But for Melissa, 'they' was the pronoun that made sense evoking the liquidy, expansiness, and even plurality they experience" (12). The use of pronouns to be gender inclusive or gender expansive challenges the social construction of gender and the technological construction of grammar. When referring to a single person as they, do I use a singular or plural verb and how often will my brain spit out a plural regardless of personal caution. "When I use 'she' by accident, I've decided not to consider myself immoral or even impolitic, just . . s slow. But sincere. And committed to learning this new grammar--and its implied post-structuralist 
worldview, as well as the many-in-one, something akin to the absorbing paradox of Chrisitanity's Trinity" (13). The multiplicity and oneness of they as a personal pronoun fits a robust theological tradition smashed by Enlightenment individualism. Has western Christianity rewired our brains with a toxic individualism and gender binary through the technology of language in story and grammar? Can "they" undo hundreds of years of rewiring personhood from autonomous, individuality to being in the image of a multiply triune oneness? Virginia Heffernan wonders "while trying to shake awake my stubborn left brain, I've begun to wonder whether resentment over new populations, new idioms, and new dialects--xenophobia and bigotry--is grounded, in part, in shame over cognitive limitations. Is it possible some would rather be known as racists than as cognitively ossified" (12)? We need a turn to a new subject. “This challenge of Melissa's 'they' has made me child-like. And in that way, I feel more, not less, like a human being” (Heffernan 2019, 13).

Story Three: "Nevertheless, the Valley's vision for a transformed humanity is protected from critical examination by its central tenet of faith: Innovation is always good, and more is always better" (20). A theology of abundance is often the praise refrain of many a Christian congregation. So, what's wrong with infinite and limitless abundance? Reflecting on the social impact of a past technological revolution, Gaymon Bennett reminds me of the impact of the industrial revolution, which "effectively cut off the human person from the earth, from daily connection to family, from spontaneous creativity, and ultimately--in the view of many activists-from life lived in the divine image" (21). In response, a new Christian theology and movement developed called the Social Gospel and supported in theological schools by the disciplinary arm of my training, social ethics. A movement away from individual sin and privatized belief was replaced with analysis of social sin and seeking of justice in the here and now. Will this faithful response to a massive technological shift and its latter iterations in liberation theologies serve us in a digital rather than industrial age? In an unprecedented fashion, digital technology gives "us new ways of activating and inhabiting our connections to one another--and that can't be taken for granted. But in doing so they've also 'algorithmized' life ...” (21). (Bennett 2019)

\section{The Stories of Technology}


We are well passed the era when technologists claimed digital technology and the internet in particular would offer a utopian space free of social sins like racism, sexism, ableism, and so on. No technology is morally neutral. Digital technology allows us to expand our multiplicity in new ways through networked relationship unbound by geography and time, yet it also reinforces confining and disciplining powers of social sin created first by humans and maximized through algorithms and machine learning. Theologians Brad Kallenberg and John Dyer help us to understand this.

They talk about the three stories that we tell about and with technology (Kallenberg 2011, Chap 4 and 5; Dyer 2011, Chap 1). For both, the first story is that of technology as tool, an instrumentalization of technology that assumes humans are in control of technology. The second story is about culture and how humans shape the world through the tools they use. The third story for both admits of a co-constitutive view of technology that is not fully determined by human or tool. Admittedly Dyer and Kallenberg take the notion of technological stories from Heidegger adding their own spin. Kallenberg says "technology is 'revealing' (das Entbergen). By this mysterious gerund, Heidegger is alluding to the fact that technology, and its cumulative effects, takes on a life of its own in that it is able to reveal a message or tell a story akin to a human teller" $(2011,112)$. Dyer describes the third story this way, "the third and final story we tell with technology happens when all that transforming we do to the world and ourselves finds its way into our souls" $(2011,40)$. In the third story, technology reveals something about us in ways that reconstitute who we are (Kallenberg, 2011, 113).

The third story provides the interpretation of digital technology that most of us experience on a daily basis. We shape our technologies and they shape us. In a digital landscape of artificial intelligence, big data, and infinite upgrades, we can literally see and feel that "technology is neither our dictator (technological determinism) nor merely our tool (cultural determinism) but something much closer to us, under the skin or in the blood, as it were" (Kallenberg 2011, 117). There are in fact ways that digital technology reconstitutes fleshly existence through appendages and enhancements. Far more pervasive may be the way digital technology changes synapses, compels affect, and plugs us into a relational network from which we are consciously (intentional use of digital media) and sometimes unconsciously (archiving of public data like street cameras, population maps, and government records) connected. We need a 
theological anthropology that robustly responds to the fact that we are digitally embodied spirits marked as connective networks or relational interdependence.

\section{A Tale of Feminisms' Theological Anthropology}

Womanist and feminist theological conversations have long sought to debunk the influence and even "correctness" of the Enlightenment subject that stands in option to a theological anthropology that is relational, interdependent, multiple, and particular. These scholars, of which I count myself, level strong critiques against the inheritance of the modernist turn to the subject, the radical quest for individualism, and resultant disembodied mind. Feminisms share a healthy skepticism of essentialism on the one hand, and also postmodernism's bent toward complete fragmentation of identity and personhood, on the other. I use the term feminisms strategically, as white, Western feminism has its origins in the Enlightenment ideals of liberty, equality and universal human rights. The disembodied rational mind of Enlightenment transcendental thought creates a very particular "person," a type of man who looks like, is educated like, and marries into the western system of masculinity. This "person" is often generic and devoid of the complex differences that feminisms articulate.

Often, this generic person, in human rights discourse, is still male in all his gendered and sexed characteristics. Rita Gross critiques this oversight in the white, Western feminist movement:

A common way of stating what that movement is all about is the call for women to be able to do whatever men can do or the claim that women are equally competent with men at most or all tasks or push for women to have the same rights that men enjoy. But notice - that kind of rhetoric assumes that what men do and the way they are is the ideal and the norm toward women should strive or which they should be allowed to attain (Gross 2003, 10).

Susan Frank Parsons elaborates, "there may be something about the Enlightenment ideal of rational choice and responsible freedom which women [and many men] cannot fully embody in this society" $(1996,52)$. Another problem arises at the same time, but in an opposite direction, the generic "man" terminology of rights leaves women excluded in socio-cultural systems employing a dual anthropology. Dual anthropology, particularly pervasive in the Roman 
Catholic tradition, renders woman a gendered subject based on "natural reproductive characteristics" determining her to be "less than" a man in the theological sphere (Bilgrien 2003, 38-40).

In response to tangible historical effects of Christianity's integration of Enlightenment philosophies, Christian feminist and womanist writings share some critical approaches with postmodernism, postcolonialism, and poststructuralism including a distrust of metanarratives, a de-centering of the "self," a newly understood notion of time, the rejection of hierarchical binary opposition, and objectivity as a standard. The rejection of hierarchical binaries leads to both a positive notion of hybridity and a possible negative regression into paralyzing differences that have the potential to cripple concrete political action. This explosion of difference and fragmentation renders objectivity a mere façade for someone else's subjectivity. Universals as read through metanarratives can no longer compel consensus, moving dialogue to a very local and specific level.

The particularity needed to deal with the fragmentation questions not only human rights dialogue, but the possibility of naming an authentic self. The "dismantling" of the self is often regarded, in sensationalist terms, as threatening to undermine most if not all familiar ideas concerning philosophy and morality. This is so because in challenging the commonplace concept of what it is to be a person - a concept as seen in modernism stemming from Descartes - it also challenges the standard visions of how we stand, or fail to stand, as knowers in relation to reality and causes disruption to the grounds of many ethico-political practices (Narayan, 2003). However, feminisms have articulated certain commitments such as a deep look at relationality, the binding of the self to and by historicity, and a starting point of particularity in personal and communal experience to resist infinite fragmentation and deconstruction. Each of these dimensions requires a self that can be known through a continuity expressed and experienced in relationship and in history.

Feminist theory in its many theo-ethical variations from white feminist to womanist, from Asian feminist to mujerista, "have become more complex and inclusive of increasingly diverse perspectives, the nature and value of difference has grown as an area of investigation ... more attention has been paid to the ways women oppress each other by race," class, colonial status, and more (Brock 1996, 120). With the impact that difference carries, feminist theories have shied away from universal, essentialist claims about the human person. In attempts to argue 
for “women's" equality, some feminists have utilized strategic essentialism (Keller 1997; Kowk and Donaldson 2002). Scholars claim coherence in certain descriptions of a social construction, biological features, and lived expressions that appear consistent, rather than absolutizing and making inevitable the description of human nature. Ivone Gebara, a Latin American ecofeminist states, "The issue of personhood goes beyond rationalistic, phenomenological, or existentialist philosophical descriptions.... To speak of the human person requires that we go beyond theorizing, beyond prescribed sequences of words, and beyond some ideal to be upheld. It means recovering the concreteness of our being: its social, ethnic, sexual, earthly and cosmic condition" (Gebara 1999, 74-75). The critical task, then, is to negotiate conflicting social, cultural, biological, and technological trajectories that reveal theological anthropology. For that task, I have chosen to engage two conversation partners: Ivone Gebara, Brazilian feminist theologian and M. Shawn Copeland, U.S. womanist moral theologian. ${ }^{1}$

Ivone Gebara describes the process that exploited the modern turn to the subject and personal autonomy. Over time, "we have gone from promoting the autonomy of individual persons to the unrestrained exercise of our passion of possessing, for self-assertion, and for power" (Gebara 1999, 72). The formulation of a free and autonomous person has been co-opted and disabused by colonialism, neocolonialism, free market capitalism, contemporary wars, technology, and more in an effort to eliminate poor people, namely those who are blacks and native peoples (Gebara 1999, 75-76). As a reaction to this trend, Gebara seeks to create a balance or new equilibrium, in what she calls an "ecofeminist" understanding of person.

Gebara names one constitutive dimension of person-relatedness and two inherent components of being - openness and evolution. She stresses relatedness as a collective dimension as more important than autonomy or individuality. In defining relatedness, she claims to speak "of a reality that seems so fundamental that it is shared by all living beings." She further describes relatedness as "more elementary than awareness of differences or than autonomy, individuality, or freedom"(Gebara 1999, 83). Gebara's description of relatedness is similar to the networked way of being inherent to digital existence including hardware

\footnotetext{
${ }^{1}$ I make move to narrow conversation partners for two reasons. First, it is folly to think one can represent all of Christian womanist and feminist thought ever, let alone in the confines of this article. Second, my own ethical commitments require me to engage non-white, western feminist and womanist thought to provide a corrective lens to my own white, U.S. privilege. This conversation requires my own awareness of racial, economic, and national privilege which I find acutely lacking in theological conversations about digital technology.
} 
connectivity, software functionality, and users' experience. Relatedness, Gebara suggests, leads one to recognize herself as more than the individuality she knows in her own consciousness, human characteristics, or human relationships. In this, relatedness "points to the vital power of the interconnection [or networkedness] among all things, independent of any anthropological ethical judgment we might make about them"(Gebara 1999, 84). Gebara develops the concept of relatedness from a variety of positions: as human condition, as reality beyond consciousness, as beyond Western rationality, as earthly condition, as ethical reality, as religious experience, and as cosmic condition. I would extend this to digital existence or condition for both humans and creation (see Ott 2018, Chap 2 and Chap 4).

The collective dimension of self as relatedness is reflected in openness and evolution as inherent components of being. Relatedness situates the self within the larger cosmic whole, a whole that defines sacred being but remains in spatial and temporal terms. In fact, Gebara's personhood deconstructs the notion of a transcendent principle or higher divinity; in a sense, her theological anthropology is both robustly anthropological and theological as it constitutes some part of sacred being. When describing openness and evolution, she further describes what a person can know in contrast to past modernist tendencies, she writes, "the ecofeminist perspective assumes that, despite the fact that we are human beings, we can know neither God nor human beings by a priori deduction"(Gebara 1999, 95) Gebara gives priority to an order of historical experience as the primary source of knowledge. As a result, Gebara does not speak of original sin or a fallen condition "refusing to place what we call ethical perfection at the beginning of all” $(1999,97)$.

Rather, Gebara affirms "the origin of ethics" as development of "our humanization process" $(1999,97)$. Gebara states that ecofeminism does not reflect on the freedom to accept or reject God as a higher divinity, "because it no longer speaks of the supreme being as an autonomous, separate person" $(1999,97$.) This is not to say that human persons are not free, rather their freedom is not completely dependent on their rationality or for the sake of an external, transcendent union with God. So, ethical action arises from an interconnection with others, and a striving for right relationships in this shared life; it is a human project. There is no pre-established perfection to which to return; rather all selves have an evolutionary openness to a changing vision and growing perception of human flourishing. This may sound a bit like the 
limitless abundance that Bennet warns against in story three shared above, and a lack of awareness of suffering and evil.

Gebara's claims about historical contextuality of all personhood is grounded in a material, and historical view of suffering and evil. She reminds us that "From the moment we speak of crosses in the plural, the cross of Jesus becomes one among many" $(2002,120)$. Then we must consider the other crosses, she asks, "Is it not precisely the innocent, the marginalized and excluded, and those who fight for justice and human rights who often bear the heaviest crosses, the most paradoxical ones?" (Gebara 2002, 120). She does not want to absolutize one form of suffering or one way of conceiving of God's saving action in the world. If the poor black Brazilian woman dies because of the sin of social systems and individual neglect, is that not God crucified today? Salvation then is equally contingent for Gebara. By paying close attention to the lived realities of poor women throughout her city, she suggests, "salvation seems to be a movement toward redemption in the midst of the trials of existence, one moment of peace and tenderness in the midst of daily violence, beautiful music that calms our spirit, a novel that keeps us company" or a text message that makes us smile, a voice note from a child (Gebara 2002, 124). "For them salvation is not a point of arrival but a little oasis in the midst of daily trails" (Gebara 2002, 125). When suffering and salvation are particularized both in the incarnate life of Jesus and that of poor Brazilian women, we can acknowledge eschatological visions of justice to come and the current lack of fulfillment.

Similar to Gebara, M. Shawn Copeland centralizes the particularity of human experience of oppression as primary to the theological task and even to theological anthropology. She writes, "this risk may place us in the path of grace: to take oppression as a point of departure for theological reflection brings about encounter with the purifying powers of God in history" (2010, 91). Her commitment to centralizing the experience of human oppression, especially that of poor women of color, is in direct response to "The Enlightenment era's 'turn to the subject' [which] coincided with the dynamics of domination" $(2010,88)$. In the dynamics of domination, Copeland includes anti-semitism, mysogyny, racism, colonialism, and heterosexism to name a few. Her new anthropological subject comes directly from her reading of Jesus' incarnational life. She both particularizes Jesus' life and ministry under empire and universalizes him as she writes, "we are his very own flesh" $(2010,82)$. She means this in a physical and metaphorical 
sense. Leaving open the possibility that our online incarnations are also part of 'his very own flesh.'

Copeland uses flesh in multiple ways when connecting humanity to Jesus in her articulation of theological anthropology. She relies on the historical act of Jesus' incarnation for the connection between divine and human in her anthropology, though she materalizes it based on actions of solidarity which remake the marks of flesh or body. Copeland never speaks of a Christ disconnected from Jesus' marked embodiment that was raced, gender, sexed, religious, and culturally known. She writes,

"The body of Jesus the Christ, both before and after his death, radically clarifies the meaning of be-ing embodied in the world. His love and praxis releases the power of God's animating image and likeness in our red, brown, yellow, white, and black bodies-our homosexual and heterosexual bodies, our HIV/AIDS infected bodies, our starving bodies, our prostituted bodies, our yearning bodies, our ill and infirm bodies, our young and old and joyous bodies" (2010, 82-83).

The "bodies of the victims of history" are not the anthropological subjects of Enlightenment era theology or philosophy (Copeland 2010, 84). In fact, they are made so by technologies created out of Enlightenment progress, like chattel slavery, colonialism, and sexual exploitation. As we look to incarnations online and created through digital surveillance, the 'bodies of the victims of history' are overdetermined through technologies that still embody racist colonial sexual exploitation (Noble 2018, Eubanks 2017).

When we start with the particularity of suffering and oppression, even in Jesus' life we uncover practices and possibilities for both momentary liberation and motivation to create a more just world. Copeland argues that "solidarity begins in an anamnesis, which intentionally remembers and invokes the black victims of history, martyrs for freedom. Theologically considered, their suffering, like the suffering of Jesus, seeds a new life for the future of all humanitiy" $(2010,124)$. The body of Christ is multiplicity and oneness simultaneously. It is both historically located and across time. It is marked by exploitation and violence and repeatedly challenges these through practices of solidarity. This is the theological anthropology in which we participate and one that perhaps is best suited for our digital spiritual embodiment.

From Gebara and Copeland's work, we receive a theological anthropology rooted in relationality, historical contextuality for human persons and God as evidenced through the life of 
Jesus, and multiplicity through particular human experiences in the shared suffering of God. These features of theological anthropology share a commitment to the momentary in-breaking of justice that recognizes, respects, and even extends difference providing diverse eschatological visions, named as openness and evolution by Gebara. When considering digital spiritual embodiment, these aspects of theological anthropology, and what they stand in opposition to, can guide us in discerning the productive and deformative aspects of digital existence.

\section{Defining Stories}

The third story of digital technology, humans as co-constitutive with digital technology, reminds us that humans have always been technologically embodied spirits if we look to the use of language, farming, craft making, building, and so on. Thus, the claim that we are digitally embodied spirits is a specification of or a historical redundancy in the project of theological anthropological claims. For example, the outsourcing of my memory to an online calendar shares a genesis in the technology of writing and recording on a paper calendar. However, the online calendar is also programmed to remind me of the appointment utilizing a variety of networked pathways that connect back to me. Similarly, the existence of fragmented pieces of who I am in the form of avatars, evidences the same multiplicity of being as the way I show up at the gym versus my classroom versus my home. In some cases, there is coherence among these selves and at other times, the only coherence is the connection they have back to the originator. Digital technologies amplify and amend prior technological ways of being rather than completely supplanting them.

Gebara and Copeland call us to look at the particularity, including the historical context, of those most severely impacted by structures of injustice. Their stories fix a self-image out of which we can better understand theological anthropology. There, we find incarnation, the body of Christ in its multiple suffering. How do we theologically understand the online beating and rape of Anita Sarkeesian's image as retaliation for speaking up against racial and sexual violence in video games? (https://en.wikipedia.org/wiki/Anita_Sarkeesian) In whose body do we recognize Christ's suffering when a Google search for "black girls" returns sexually derogatory, racist, pornographic videos? (Noble 2018, 67, Google has since removed these search results.) These violations are not simply a product of human sin. The digitization of the self makes 
possible new forms of violence. Thus it also makes possible new forms of liberation, like gender configurations through digital measurable types that socially construct a multiple way of being in the world making most of us trans in ways we never imagined possible (Ott 2018, 60). Salvation momentarily breaks through when Bana Alabed, at eight years old, uses a Twitter account to document, to make visible the 'bodies of the victims of history' in the Syrian conflict (Pimentel et al. 2018).

The theological anthropology proposed by feminist and womanist theologians has for decades prior to digital technologies given us clues to how to respond as relational, interdependent, and multiple selves in community and in communion with God. The reality of that task has never underestimated the brokenness and suffering caused by systemic oppression, evidenced in everyday interaction. It is equally true that the "inspirited digital body is as morally entangled with sociocultural oppression now as in the analog past" and it is liberated into new ways of being the relational, interdependent, and multiple image of God that it is created to be (Ott 2018, 63). Similarly, Kallenberg writes, "however, precisely because technology embodies human intention, human interaction with technological artifacts can mold or deform the dispositions and character of those who engage it every bit as much as interactions with other person's shapes our dispositions and character" (Kallenberg 2011, 108). As digitally embodied spirits we more deeply inhabit our relationality, interdependence, and multiplicity creating more entangled modes of oppression as well as generating liberative salvific moments.

\section{Bibliography}

Campbell, Heidi and Stephen Garner. 2016. Networked Theology: Negotiating Faith in Digital Culture. Grand Rapids, MI: Baker Academic.

Gaymon Bennett. 2019. "Silicon Valley’s Original Sin” in Sojourners. p. 17-21, 42.

Bilgrien, Sister Marie Vianney. 2003. "The Voice of Women in Moral Theology." In Moral Issues and Christian Responses, edited by Patricia Beattie Jung and Shannon Jung, 3743. Belmont: Thomson Wadsworth.

Brock, Rita Nakashima. 1996. "Feminist Theories." In Dictionary of Feminist Theologies, edited by Letty Russell and Shannon Clarkson. Louiseville: Westminister John Knox. p 116-20. 
Cady, Linell Elizabeth. 1997. "Identity, Feminist Theory, and Theology." In Horizons in Feminist Theology: Identity, Tradition, and Norms, edited by Rebecca S. Chopp and Sheila Greeve Davaney. Minneapolis, MN: Fortress. p 17-32.

Chopp, Rebecca S.1997. "Theorizing Feminist Theology." In Horizons in Feminist Theology: Identity, Tradition, and Norms, edited by Rebecca S. Chopp and Sheila Greeve Devaney. Minneapolis: Fortress. p 215-31.

Donaldson, Laura E., and Pui-lan Kwok. 2002. Postcolonialism, Feminism and Religious Discourse. New York: Routledge.

Dyer, John. 2011. From the Garden to the City: The Redeeming and Corrupting Power of Technology. Grand Rapids, MI: Kregel Publications.

Eubanks, Virginia. 2018. Automating Inequality: How High-Tech Tools Profile, Police, and Punish the Poor. St. Martin's Press.

Gebara, Ivone. 1999. Longing for Running Water : Ecofeminism and Liberation. Minneapolis, MN: Fortress Press.

Gebara, Ivone. 2002. Out of the Depths: Women's Experience of Evil and Salvation. Minneapolis, MN: Fortress Press.

Gross, Rita M. 2003. "What Went Wrong?" Cross Currents 53, no. 1: 8-21.

Virginia Heffernan. 2019. "Brain Nonbinary the Problem of Deep Grooves" in Wired March 2019, 11-13.

Amanda Hess. 2016. "What Do Our Online Avatars Reveal About Us?" New York Times, May 10, 2016. Accessed October 15, 2019 at https://www.nytimes.com/2016/05/15/magazine/whatdo-our-online-avatars-reveal-about-us.html

Kallenberg, Brad J. 2011. God and Gadgets: Following Jesus in a Technological Age. Eugene, OR: Cascade Books.

Keller, Catherine. 1997. "Seeking and Sucking: On Relation and Essence in Feminist Theology." In Horizons in Feminist Theology: Identity, Tradition, and Norms, edited by Rebecca S. Chopp and Sheila Greeve Davaney. Minneapolis, MN: Fortress. p. 54-78

Narayan, Uma. "The Project of Feminist Epistemology: Perspectives from a Nonwestern Feminist." In Feminist Theory Reader: Local and Global Perspectives, edited by Carole R. and Seung-Kyung Kim McCann, 308-17. New York: Routledge, 2003.

Noble, Safiya Umoja. 2018. Algorithms of Oppression: How Search Engines Reinforce Racism. New York: NYU Press. 
Oduyoye, Mercy. 1988. "Be a Woman, and Africa Will Be Stong," in Inheriting Our Mothers' Gardens: Feminist Theology in Third World Perspective, ed. Kwok Pui lan, Ada María IsasiDíaz, Katie Geneva Cannon, Letty M. Russell. Louisville, KY: Westminster John Knox Press.

Parsons, Susan Frank. 1996. Feminism and Christian Ethics, New Studies in Christian Ethics. Cambridge: Cambridge University Press.

Pimentel, Julia, Carolyn Bernucca, and Khal. 2018. "20 Young Activists Who Are Changing the World." Complex, December 22. Available online: https://www.complex.com/life/youngactivists-who-are-changing-the-world/ (accessed on 26 August 2019). 